\title{
Nuclear Magnetic Resonance Spectroscopy. Carbon-13 Chemical Shifts of Small Peptides as a Function of $\mathrm{pH}^{1}$
}

\author{
Manfred Christl ${ }^{2}$ and John D. Roberts* \\ Contribution No. 4257 from the Gates and Crellin Laboratories of Chemistry, \\ California Institute of Technology, Pasadena, California 91109. \\ Received May 26, 1971
}

\begin{abstract}
Carbon-13 spectra of 27 peptides have been obtained by high-resolution nmr spectroscopy with the aid of proton decoupling. The chemical shifts of the different amino acid moieties are found to have systematic deviations from those of the free zwitterionic amino acids. These effects depend very largely on the position of an amino acid in a peptide, i.e., on whether it is a C-terminal, an N-terminal, or a nonterminal unit, but not on the nature of its neighbors in the chain, unless one of these is proline. The results have substantial value for the determination of amino acid sequences in di- and tripeptides. Protonation and deprotonation of zwitterionic peptides have considerable effects on the chemical shifts which are, for the most part, limited to the amino acid units directly involved in the reaction. The one important exception to this rule that we have observed is interpreted as being the consequence of a conformational change which the peptides undergo when transformed from the zwitterion to the anion or cation.
\end{abstract}

$\mathrm{N}$ umerous publications in recent years emphasize the potential of $\mathrm{nmr}$ investigations on amino acids, peptides, and proteins. ${ }^{3}$ The application of proton $\mathrm{nmr}$ to proteins, however, was shown to be limited because of the large number of different types of protons in a protein combined with a relatively small spread in chemical shifts and large intrinsic line widths. Specific deuteration of proteins results in much simpler proton spectra and allows more detailed studies. The carbon-13 (cmr) spectra of amino acids ${ }^{4}$ show much larger chemical shift differences than for the corresponding proton spectra. This fact provides promise with regard to the resolution of specific resonances in the spectra of peptides and proteins. Several recent papers offer results in accord with this prediction..$^{5-9}$ Proteins with specifically labeled carbon- 13 amino acids can now be confidently expected to provide detailed information concerning the three-dimensional structure of proteins in solution and interactions of protein with small molecules.

We report here the results of a systematic $\mathrm{cmr}$ investigation carried out on small peptides with ${ }^{13} \mathrm{C}$ of natural abundance. The objective of this study was to see if $\mathrm{cmr}$ spectroscopy could be developed to be useful for the determination of the amino acid sequences in di- and tripeptides, particularly through possible $\mathrm{pH}$ dependences of the carbon chemical shifts.

(1) Supported by the Public Health Service, Grant No. GM-11072-07, from the Division of General Medical Sciences.

(2) Max Kade Foundation, Inc., Fellow, 1970-1971

(3) For a review, see G. C. K. Roberts and O. Jardetzky, Advan. Protein Chem., 24, 447 (1970)

(4) W. Horsley, H. Sternlicht, and J. S. Cohen, J. Amer. Chem. Soc., 92, 680 (1970)

(5) W. A. Gibbons, J. A. Sogn, A. Stern, L. C. Craig, and L. F. Johnson, Nature (London), 227, 840 (1970).

(6) A. Allerhand, D. Doddrell, V. Glushko, D. W. Cochran, E. Wenkert, P. J. Lawson, and F. R. N. Gurd, J. Amer. Chem. Soc., 93, 544 (1971).

(7) A. Allerhand, D. W. Cochran, and D. Doddrell, Proc. Nat. Acad. Sci. U.S., 67, 1093 (1970)

(8) G. Jung, E. Breitmaier, and W. Voelter, Angew. Chem., Int. Ed. Engl., 9, 894 (1970).

(9) J. S. Cohen, M. H. Freedman, and I. M. Chaiken, Biochem. Biophy.s. Res. Commun., 42, 1148 (197i).

\section{Experimental Section}

The peptides examined in the present research were all commercial materials and were used without further purification. The noisedecoupled $\mathrm{cmr}$ spectra of aqueous solutions were obtained with the digital-sweep spectrometer described earlier. ${ }^{10}$ Water protons provided the internal field-frequency lock; the solutions of the peptides in water gave $\mathrm{pH}$ values between 5.3 and 5.9, which are characteristic of zwitterions. 11 Solutions of the cations and anions of the peptides were obtained by either adjusting the $\mathrm{pH}$ to 1.5 by adding hydrochloric acid, or to 9.5 by adding sodium or tetramethylammonium hydroxide, respectively. The published $\mathrm{p} K$ data ${ }^{11}$ for peptide carboxyl groups of 2.8-3.3 and peptide ammonium groups of 7.7-8.5 suggest that high percentages of the carboxylate and ammonium groups are protonated at $\mathrm{pH} 1.5$ and deprotonated at pH 9.5, respectively. Only in a few special cases were more extreme $\mathrm{pH}$ values used, especially because, with the heating produced by proton decoupling, hydrolysis of the peptides could become important over the long scanning periods required. Furthermore, at pH's above 10 , general line broadening was observed which changed the signal-to-noise ratios and, consequently, the scanning times in a disadvantageous manner. The $\mathrm{pH}$ values were determined with a Radiometer $\mathrm{pH}$ meter. The chemical shifts reported here were measured relative to the resonance of internal tetramethylammonium cation and corrected to carbon disulfide as external reference by the relation $\delta_{\mathrm{Cs}_{2}}=\delta_{\mathrm{N}\left(\mathrm{CH}_{3}\right)_{4}{ }^{+}+}+$ $137.0 \mathrm{ppm}$. The reproducibility was about $0.1 \mathrm{ppm}$. The assignment of the resonances to specific carbons was made on the basis of the chemical shifts of the free amino acids published by Sternlicht and coworkers. 4 In some ambiguous cases, single-frequency decoupling of s!recific protons was helpful.

\section{Results}

The cmr chemical shifts of 16 dipeptides, 9 tripeptides, tetraglycine, and pentaglycine have been determined at different $\mathrm{pH}$ values. Because of low solubilities, some compounds could not be examined at the available sensitivity as zwitterions. Table I shows the values of glycine units in 13 different peptides classified according to their position in the peptide chain (C-terminal, N-terminal, or nonterminal position) and on the $\mathrm{pH}$. With respect to the $\mathrm{pH}$, knowing that a peptide can exist as cation, zwitterion, and anion, we can expect that an amino acid as a peptide unit (1968)

(10) F. J. Weigert and J. D. Roberts, J. Amer. Chem. Soc., 90, 3543

(11) E. J. Cohn and J. T. Edsall, "Proteins, Amino Acids, and Pep. tides," Reinhold, New York, N. Y., 1943, p 84 
Table I. ${ }^{13} \mathrm{C}$ Chemical Shifts (ppm) of Glycine Units Bound in Peptides Upfield from Carbon Disulfide

\begin{tabular}{|c|c|c|c|c|c|c|c|c|c|}
\hline \multirow[b]{2}{*}{ Peptide } & \multicolumn{3}{|c|}{ Cation- } & \multicolumn{3}{|c|}{$\longrightarrow$ Zwitterion $\longrightarrow$} & \multicolumn{3}{|c|}{- Anion $\longrightarrow$} \\
\hline & $\mathrm{pH}$ & $\mathrm{C}_{0}$ & $C_{\alpha}$ & $\mathrm{pH}$ & $\mathrm{C}_{0}$ & $\mathrm{C}_{\alpha}$ & $\mathrm{pH}$ & $\mathrm{C}_{0}$ & $\mathrm{C}_{\alpha}$ \\
\hline \multicolumn{10}{|c|}{ N-Terminal Units } \\
\hline Gly(-Gly) & 1.5 & 24.9 & 151.6 & 5.7 & 25.2 & 151.5 & 9.5 & 19.1 & 149.0 \\
\hline Gly(-Leu) & 1.6 & 25.3 & 151.6 & 5.9 & 25.9 & 151.6 & 9.6 & 19.4 & 149.0 \\
\hline Gly(-Phe) & 1.4 & 25.3 & 151.7 & 5.5 & 26.0 & 151.6 & 9.6 & 19.4 & 148.9 \\
\hline Gly $(\cdot$ Gly-Gly) & 1.4 & 24.5 & 151.4 & 5.4 & 24.3 & 151.5 & 9.4 & 18.0 & 148.9 \\
\hline Gly(-Leu-Gly) & 1.5 & 24.9 & 151.6 & 5.5 & 24.8 & 151.5 & 9.5 & 18.2 & 148.8 \\
\hline Gly(-Leu-Tyr) & 1.5 & 25.2 & 151.7 & 5.5 & 25.3 & 151.6 & 9.5 & $\begin{array}{c}18.9 \\
(17.8)\end{array}$ & 148.9 \\
\hline Gly(-Gly $)$ & 1.1 & 24.5 & $\begin{array}{c}151.6 \\
(151.3)\end{array}$ & & & & 10.2 & $\begin{array}{c}15.9 \\
(16.1)\end{array}$ & 148.5 \\
\hline Gly $\left(-\mathrm{Gly}_{4}\right)$ & 0.4 & 24.3 & $\begin{array}{c}151.5 \\
(151.1)\end{array}$ & & & & 11.2 & $\begin{array}{c}15.8 \\
(16.0)\end{array}$ & 148.3 \\
\hline \multicolumn{10}{|c|}{ C-Terminal Units. } \\
\hline (Gly-)Gly & 1.5 & 19.5 & 151.1 & 5.7 & 16.2 & 148.8 & 9.5 & 16.3 & 149.0 \\
\hline (Leu-)Gly & 1.5 & 19.4 & 151.0 & 5.8 & 16.4 & 148.9 & 9.5 & 16.3 & 149.0 \\
\hline (Lys-)Glye & 1.6 & 19.2 & 151.0 & 6.0 & 16.5 & 148.8 & 12.6 & 15.9 & 149.0 \\
\hline (Gly-Gly-)Gly & 1.4 & 19.2 & 151.1 & 5.4 & 16.0 & 148.9 & 9.4 & 16.2 & 148.9 \\
\hline (Ala-Gly-)Gly & 1.6 & 19.0 & 151.0 & 5.4 & 16.1 & 148.9 & 9.6 & 16.0 & 148.9 \\
\hline (Leu-Gly-)Gly & 1.5 & 19.0 & 151.1 & 5.4 & 16.5 & 149.1 & 9.4 & 16.1 & 149.1 \\
\hline (Gly-Leu-)Gly & 1.5 & 19.1 & 151.1 & 5.5 & 16.2 & 148.8 & 9.5 & 16.6 & 148.8 \\
\hline (Met-Phe-)Gly & 1.4 & 19.5 & 150.9 & & & & 9.9 & 16.3 & 148.9 \\
\hline$\left(G^{\prime} y_{3^{*}}\right)$ Gly & 1.1 & 19.3 & $\begin{array}{c}151.3 \\
(151.6)\end{array}$ & & & & 10.2 & $\begin{array}{c}16.1 \\
(15.9)\end{array}$ & 149.0 \\
\hline$\left(\right.$ Gly $\left._{4}-\right)$ Gly & 0.4 & 19.2 & $\begin{array}{c}151.1 \\
(151,5)\end{array}$ & & & & 11.2 & $\begin{array}{c}16.0 \\
(15.8)\end{array}$ & 149.0 \\
\hline \multicolumn{10}{|c|}{ Nonterminal Units } \\
\hline $\begin{array}{l}\text { (Gly-)Gly(-Gly) } \\
\text { (Ala-)Gly(-Gly) }\end{array}$ & $\begin{array}{l}1.4 \\
1.6\end{array}$ & $\begin{array}{l}20.8 \\
21.0\end{array}$ & $\begin{array}{l}149.8 \\
149.8\end{array}$ & $\begin{array}{l}5.4 \\
5.4\end{array}$ & $\begin{array}{c}21.4 \\
21.8 \\
(20.8)\end{array}$ & $\begin{array}{l}149.7 \\
149.7\end{array}$ & $\begin{array}{l}9.4 \\
9.6\end{array}$ & $\begin{array}{l}21.2 \\
21.2\end{array}$ & $\begin{array}{l}149.8 \\
149.8\end{array}$ \\
\hline (Leu-),Gly(-Gly) & 1.5 & $\begin{array}{c}21.0 \\
(21.1)\end{array}$ & 149.9 & 5.4 & $\begin{array}{c}22.1 \\
(21.5)\end{array}$ & 149.9 & 9.4 & 21.3 & 149.9 \\
\hline (Leu-)Gly(-Leu) & 1.5 & $\begin{array}{c}21.6 \\
(21.8)\end{array}$ & 150.0 & & & & 9.5 & 21.9 & 149.7 \\
\hline (Gly-)Gly 2 (-Gly) & 1.1 & $\begin{array}{l}20.6 \\
20.6\end{array}$ & $\begin{array}{l}149.9 \\
150.1\end{array}$ & & & & 10.2 & $\begin{array}{l}19.9 \\
21.0\end{array}$ & $\begin{array}{l}149.8 \\
149.8\end{array}$ \\
\hline (Gly-)Gly ${ }_{3}(-$ Gly) & 0.4 & 20.4 & 149.7 & & & & 11.2 & 19.9 & 149.7 \\
\hline & & $\begin{array}{l}20.4 \\
20.4\end{array}$ & $\begin{array}{l}149.7 \\
149.9\end{array}$ & & & & & $\begin{array}{l}20.3 \\
21.1\end{array}$ & $\begin{array}{l}149.7 \\
149.7\end{array}$ \\
\hline
\end{tabular}

a Uncertain assignments are shown with the nearest uncertain shift value in parentheses. ${ }^{b}$ The amino acid unit shown outside the parentheses is the one for which the given shifts apply. 'Chemical shifts for the dication, cation, and anion, respectively.

can have nine different shift situations if we assume that all of the nonterminal positions are essentially equivalent. The data in Table I are arranged to show each of these situations. The same kind of information for the other amino acids involved in our study is given in Table II. The assignments have not been proven in all cases; this is especially important for those peptides with units which have similar chemical shifts for both the $\alpha$ carbons and the $\alpha$ protons (a situation which prevents making assignments by singlefrequency proton decoupling). In such cases, the assignments given in Tables I and II are based on comparisons of two peptides, both of which have one and the same amino acid in the same position. Decoupling of specific protons led to the unequivocal assignment of the terminal $\alpha$ carbons in the tetraand pentaglycine anions wherein the resonance frequencies of the corresponding protons have been established by Nakamura and Jardetzky ${ }^{12}$ by specific deuteration. When an assignment given in Table I and II is uncertain, the nearest uncertain chemical shift value is added in parentheses. For comparison purposes, the chemical shifts of the free zwitterionic amino acids are shown in Table III. These values are

(12) A, Nakamura and O. Jardetzky, Biochemistry, 7, 1226 (1968). from Sternlicht and coworkers 4 and are corrected to carbon disulfide as external reference by the relation $\delta_{\mathrm{CS}_{2}}=\delta_{\mathrm{Gly}(\mathrm{CH}:)}+150.9 \mathrm{ppm}$.

\section{Discussion}

A. Zwitterionic Peptides. Table I shows that, over the range of peptides we have studied, the chemical shifts of a glycine unit are, without exception, affected only by its position in the zwitterionic peptide and not by the nature of the amino acids to which it is linked by means of peptide bonds. Thus, it is immaterial if we look at leucylglycine or lysylglycine, because the chemical shift of the glycine moiety is, within our experimental error, the same in both peptides. There is, however, a considerable difference between the $\mathrm{cmr}$ shifts of leucylglycine and glycyleucine. Similar behavior has been observed for the proton spectra of peptides containing glycine by Nakamura and Jardetzky. ${ }^{13}$ It has been reported earlier ${ }^{14}$ that the ${ }^{13} \mathrm{C}$ spectrum of zwitterionic diglycine consists of four peaks, the positions of which differ considerably from those of free glycine. Starting with the chemical shifts of

(13) A. Nakamura and O. Jardetzky, Proc. Nat. Acad. Sci. U. S. 58, $2212(1967)$.

(14) W. Horsley and H. Sternlicht, J. Amer. Chem. Soc., 90, 3738 (1968). 
free glycine, we might proceed in the following way to predict the shifts for the glycine carbons in an $N$-aminoacylglycine (1). In the first place, the aminoacyl group

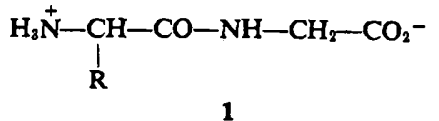

on the nitrogen is a $\gamma$ substituent for the glycine carboxylate carbon and should therefore produce a small upfield shift of the latter. ${ }^{4,14,15}$ Second, the glycine $\alpha$ carbon should exhibit an upfield $\gamma$ effect from the CHR carbon, but also a moderate downfield $\beta$ effect, the result of which should probably be a small downfield shift, as has been shown to occur in other cases for acylation, at least with acetyl groups. ${ }^{16}$ Table I reveals that only the latter expectation is in fact realized. On the average, the glycine $\alpha$ carbons in $N$-aminoacylglycines absorb $2 \mathrm{ppm}$ downfield from the resonance in free glycine, but the carboxylate carbons are also shifted downfield by about $3.3 \mathrm{ppm}$. Presumably, the expected upfield shift is masked by some other larger downfield shift, the origin of which we do not understand at present.

In glycylamino acids (2), the peak of the glycine

$$
\mathrm{H}_{3} \stackrel{+}{\mathrm{N}}-\mathrm{CH}_{2}-\mathrm{CO}-\mathrm{NH}-\underset{\mathrm{R}}{\mathrm{CH}}-\mathrm{CO}_{2}^{-}
$$

carbonyl carbon appears more than $5 \mathrm{ppm}$ upfield from the corresponding resonance in free glycine This is the expected order of magnitude because the substitution of the oxygen by a nitrogen should lead to an upfield shift of about $15-20 \mathrm{ppm},{ }^{14}$ which should be lowered by about 5-10 ppm by the combined $\beta$ and $\gamma$ effects $^{1.5}$ of the substituent on the nitrogen. The $\alpha$ carbon resonance, however, should be affected primarily by the $\gamma$ effect of the additional substituent and is shifted upfield by $0.7 \mathrm{ppm}$, a value which would have been expected to be somewhat larger. ${ }^{15}$ The $\mathrm{C}$ - and $\mathrm{N}$-terminal glycine units in zwitterionic tripeptides should show the same chemical shifts as in tripeptides because the substitution in the near neighborhood of the groups under consideration is not different. This is in fact true, except for the carbonyl carbon in $\mathrm{N}$ terminal glycine units. Those of the tripeptides absorb on the average about $0.9 \mathrm{ppm}$ downfield from those of dipeptides. Possible explanation for this effect will be discussed later. Compared to the free amino acid, glycine, as the middle unit in a tripeptide (3), is sub-<smiles>[R]C(N)C(=O)NCC(=O)NC([R])C(=O)[O-]</smiles>

stituted at the carbonyl and the amino group. This would be expected to lead to a composite sum of the effects experienced by $\mathrm{C}$ - and $\mathrm{N}$-terminal glycines. These effects have different signs; therefore, chemical shifts intermediate between those of $\mathrm{C}$ - and N-terminal glycines are predicted and found, as Table I shows.

(15) D. M. Grant and E. G. Paul, J. Amer. Chem. Soc., 86, 2984 (1964). (16) (a) G. W. Buchanan and J. B. Stothers, Can. J. Chem., 47, 3605 (1969); (b) H. J. Reich, M. Jautelat, M. T. Messe, F. J. Weigert, and J. D. Roberts, J. Amer. Chem. Soc., 91, 7445 (1969).
The carbonyl carbon resonance is upfield by $2 \mathrm{ppm}$ and that of the $\alpha$ carbon downfield by 1 ppm from the corresponding values in free glycine, a somewhat different result from what has been published earlier. ${ }^{14}$

The shift regularities, seen for glycine units in zwitterionic peptides, can be applied, at least qualitatively, to the other amino acids as peptide units. Again, only the position of the amino acid within the peptide has practical influence on the chemical shifts, the nature of the neighboring amino acids being small, with the one exception of proline. The amino acids bound to the nitrogen of a proline are affected by the special structural characteristics of this cyclic amino acid, at least for phenylalanylproline and phenylalanylprolylarginine. The phenylalanyl $\alpha$ carbon, for example, absorbs at more than $1 \mathrm{ppm}$ at higher field than in phenylalanylmethionine or phenylalanylarginine. This is probably caused by an additional $\gamma$ steric effect exerted only by proline (4). No systematic

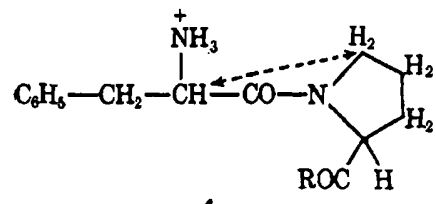

"proline shift" seems to appear at the carbonyl carbon, possibly because of the additional $\beta$ effect caused by the cyclic structure of proline, which is diminished by one new $\gamma$ effect. In addition, the $\gamma$ effect, arising from the proline carbonyl group, should be especially large because this interaction is vicinal on the side of a five-membered ring. ${ }^{17}$ Proton nmr suggests that two distinct species may be present with phenylalanylproline or phenylalanylprolylarginine corresponding to cis-trans isomerism at the phenylalanylprolyl peptide bond. ${ }^{18}$ Unfortunately, the obtainable signal-to-noise ratios in our work did not permit detection of a minor isomer.

Compared to the free amino acids, the C-terminal units in peptides show the same pattern of downfield shifts as observed for glycine. The largest effect is at the carboxylate carbons with $-3.5 \pm 1.0 \mathrm{ppm}$. (The deviations given here are the extremes from the average.) The $\alpha$ and $\beta$ carbons are influenced by -0.5 to $-1.5 \mathrm{ppm}$, while the $\gamma$ carbons absorb several tenths of a ppm downfield from the corresponding resonance in the free amino acids. Surprisingly, the effect is not monotonically attenuated as a function of distance from the nitrogen, because the more remote $\beta$ carbons show about the same shift as the $\alpha$ carbons, while the carboxylate carbons are even more downfield.

In $\mathrm{N}$-terminal amino acid units, the resonances of the carbonyl carbons appear on the average $5.4 \mathrm{ppm}$ at higher field than in the corresponding free amino acid while the resonance of the $\alpha$ carbons is shifted upfield, similar to the effect with glycine, by 0.9 to $1.7 \mathrm{ppm}$. The carbons of the side chains reveal only small nonsystematic deviations from the value in the free amino acids.

Only a small number of nonterminal units in a peptide chain have been examined. Except for the car-

(17) M. Christl, H. J. Reich, and J. D. Roberts, ibid., 93, 3463 (1971). (18) C. M. Deber, F. A. Bovey, J. P. Carver, and E. R. Blout, ibid. 92, $6191(1970)$. 
Table II. ${ }^{18} \mathrm{C}$ Chemical Shifts (ppm) of Amino Acid Units Bound in Peptides Upfield from Carbon Disulfidea

\begin{tabular}{|c|c|c|c|c|c|c|c|c|}
\hline Peptide $b$ & $\mathrm{pH}$ & $\mathrm{C}_{0}$ & $\mathrm{C}_{\alpha}$ & $\mathrm{C}_{\beta}$ & $\mathrm{C}_{\gamma}, \mathrm{C}-1^{e}$ & $\mathrm{C}_{b}, \mathrm{C}-2^{c, d}$ & $C_{e .}$ C-3e.d & $C-4 c$ \\
\hline \multicolumn{9}{|c|}{ N-Terminal Units, Cations } \\
\hline Leu(-Gly) & 1.5 & 21.3 & 140.2 & 152.3 & 168.6 & $170.7,171.0$ & & \\
\hline Leu(-Ala) & 1.5 & 22.1 & 140.3 & 152.5 & 168.7 & $170.6,170.8$ & & \\
\hline Leu(-Tyr) & 1.4 & 22.3 & 140.3 & 152.4 & 168.6 & $170.6,170.9$ & & \\
\hline Leu(-Phe) & 1.5 & 23.0 & $\begin{array}{c}140.2 \\
(137.9)\end{array}$ & 152.5 & 168.6 & $170.6,171.2$ & & \\
\hline Leu(-Gly·Gly) & 1.5 & 21.1 & 140.1 & 152.6 & 168.5 & $170.6,171.1$ & & \\
\hline Leu(-Gly-Leu) & 1.5 & 21.6 & 140.2 & 152.5 & 168.5 & $170.6,171.2$ & & \\
\hline & & & $(140.8)$ & $(152.9)$ & $(168.1)$ & $(170.2,171.5)$ & & \\
\hline Phe(-Leu) & 1.5 & 23.3 & $\begin{array}{r}138.0 \\
(140.5)\end{array}$ & 155.5 & 59.0 & 63.0 & 63.5 & 64.6 \\
\hline Phe(-Met) & 1.5 & 23.3 & $\begin{array}{c}138.0 \\
(140.4)\end{array}$ & 155.4 & 58.6 & 62.7 & 63.1 & 64.2 \\
\hline Phe(-Pro) & 0.9 & 24.6 & 139.2 & 156.3 & 59.0 & 62.3 & 63.1 & 64.2 \\
\hline Phe(-Arg) & 1.5 & 23.7 & $\begin{array}{c}138.2 \\
(139.6)\end{array}$ & 155.8 & 58.3 & 62.5 & 63.1 & $\begin{array}{l}04.2 \\
64.3\end{array}$ \\
\hline Ala(-Leu) & 1.5 & 21.3 & 143.0 & 175.6 & & & & \\
\hline Ala(-Gly-Gly) & 1.6 & 21.0 & 142.9 & 175.8 & & & & \\
\hline Ala(-Leu-Phe) & 0.5 & 21.2 & 143.0 & 175.5 & & & & \\
\hline Met(-Leu) & 1.5 & 23.0 & $\begin{array}{c}139.9 \\
(140.5)\end{array}$ & 162.0 & 164.4 & 178.2 & & \\
\hline Met(-Phe-Gly) & 1.4 & 23.1 & $\begin{array}{l}139.7 \\
137.0)\end{array}$ & 162.1 & 164.2 & 178.1 & & \\
\hline Val(-Met) & 0.9 & 23.9 & 133.8 & $\begin{array}{c}162.4 \\
(162.9)\end{array}$ & $\begin{array}{l}174.6 \\
175.4\end{array}$ & & & \\
\hline Lys(-Gly) & 1.6 & 21.0 & 139.3 & 162.1 & 171.4 & 166.1 & 153.0 & \\
\hline
\end{tabular}

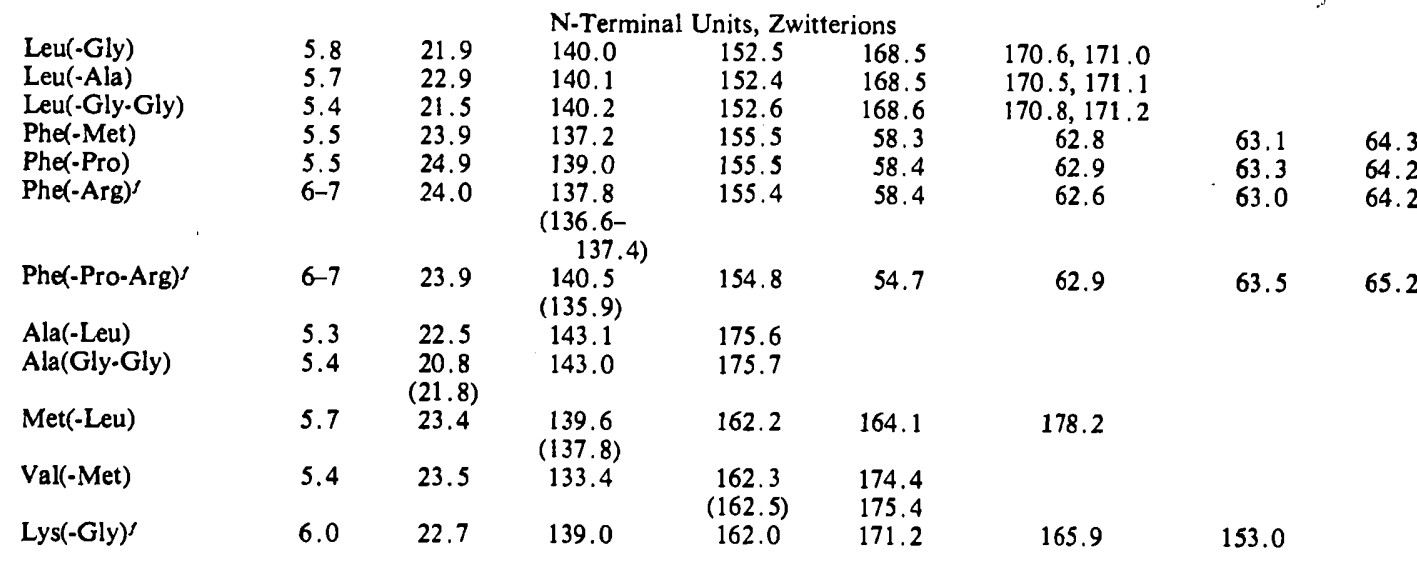

\begin{tabular}{|c|c|c|c|c|c|c|c|c|}
\hline \multicolumn{9}{|c|}{ N-Terminal Units, Anions } \\
\hline Leu(-Gly) & 9.5 & 16.3 & 139.3 & 149.7 & 168.3 & $170.1,170.8$ & & \\
\hline Leu(-Ala) & 9.5 & 16.4 & 139.2 & 149.5 & 168.4 & $170.0,170.9$ & & \\
\hline Leu(-Tyr) & 9.5 & 15.9 & 138.8 & 149.0 & 168.4 & $170.1,170.9$ & & \\
\hline Leu(-Gly-Gly) & 9.4 & 14.3 & 139.3 & 149.3 & 168.3 & $170.1,171.0$ & & \\
\hline Leu(-Gly-Leu) & 9.5 & 14.1 & $\begin{array}{l}139.1 \\
(138.4)\end{array}$ & 149.1 & 168.2 & $170.1,170.9$ & & \\
\hline Phe(-Leu) & 9.5 & 17.2 & 136.3 & 152.5 & $\begin{array}{r}55.7 \\
55.91\end{array}$ & $\begin{array}{c}(109.0,111.3) \\
63.0\end{array}$ & 63.7 & 65.7 \\
\hline Phe(-Met) & 9.5 & 14.8 & $\begin{array}{r}(138.6) \\
136.6- \\
137.4\end{array}$ & 152.3 & 55.4 & 62.8 & 63.5 & 65.2 \\
\hline $\begin{array}{l}\text { Phe(-Pro) } \\
\text { Ala(-Leu) }\end{array}$ & $\begin{array}{r}10.5 \\
9.6\end{array}$ & $\begin{array}{l}17.5 \\
16.2\end{array}$ & $\begin{array}{l}138.0 \\
142.3\end{array}$ & $\begin{array}{l}151.3 \\
173.0\end{array}$ & 55.4 & 63.4 & 63.7 & 65.4 \\
\hline Ala(-Gly-Gly) & 9.6 & 14.3 & 142.3 & 172.7 & & & & \\
\hline Met(-Leu) & 9.6 & 16.3 & $\begin{array}{c}138.3 \\
(138.5)\end{array}$ & 158.8 & 163.1 & 178.1 & & \\
\hline Met(-Phe-Gly) & 9.9 & 15.4 & $\begin{array}{c}138.4 \\
(137.9)\end{array}$ & 159.1 & 163.5 & 178.3 & & \\
\hline Val(-Met) & 9.9 & 16.4 & 131.8 & 160.7 & 173.4 & & & \\
\hline Lys(-Gly) & 12.6 & 14.8 & 137.7 & 158.2 & 170.3 & 160.9 & 1519 & \\
\hline
\end{tabular}




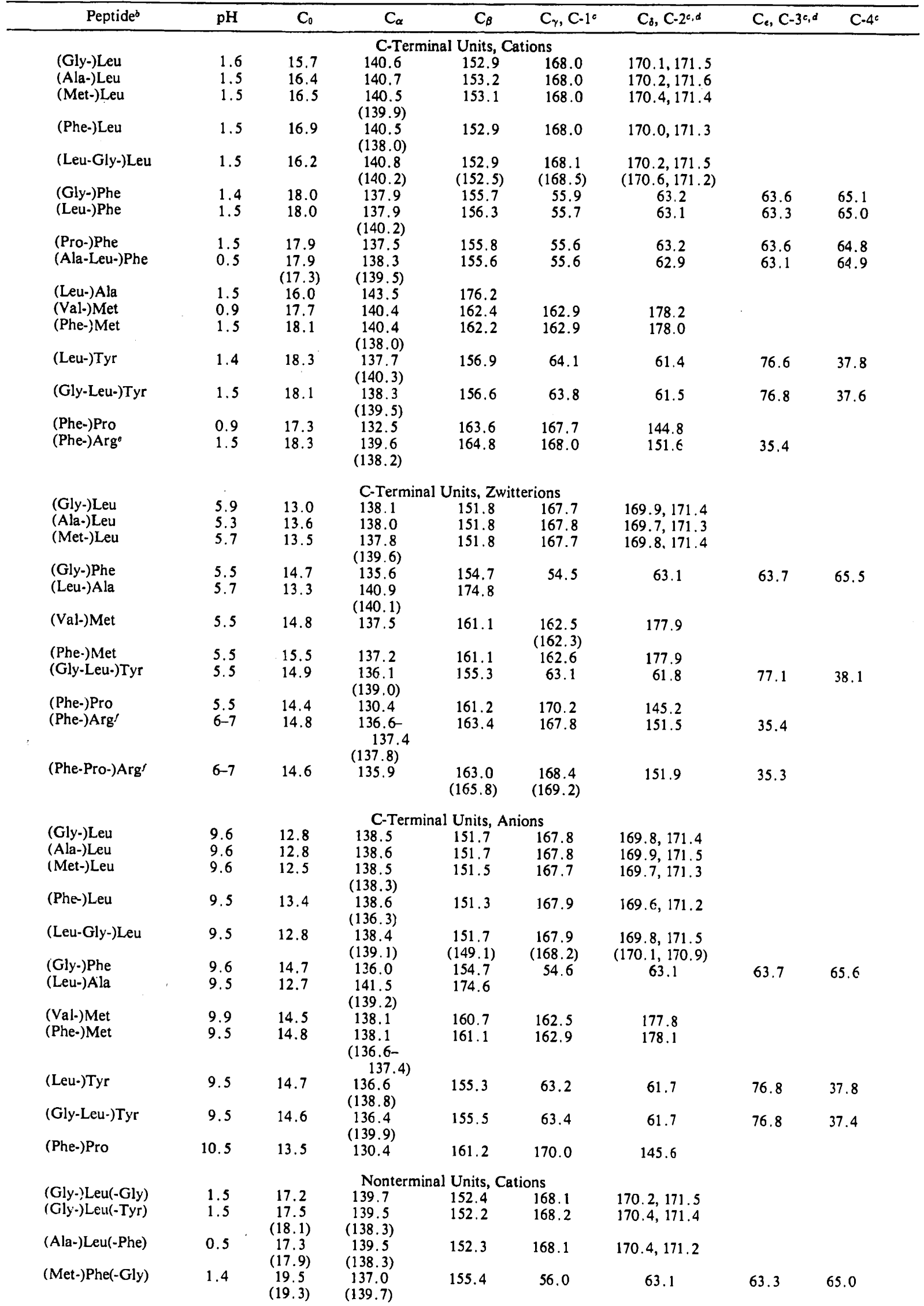


Table II (Continued)

\begin{tabular}{|c|c|c|c|c|c|c|c|c|}
\hline Peptide $^{b}$ & $\mathrm{pH}$ & $\mathrm{C}_{0}$ & $\mathrm{C}_{\alpha}$ & $C_{\beta}$ & $\mathrm{C}_{\gamma}, \mathrm{C}-1^{\circ}$ & $\mathrm{C}_{\delta}, \mathrm{C}-2^{c_{1} d}$ & $\mathrm{C}_{e}, \mathrm{C}-3^{e, d}$ & $C-4^{c}$ \\
\hline $\begin{array}{l}\text { (Gly-)Leu(-Gly) } \\
\text { (Gly-)Leu(-Tyr) } \\
\text { (Phe-)Pro(-Arg) }\end{array}$ & $\begin{array}{l}5.5 \\
5.5 \\
6-7\end{array}$ & $\begin{array}{l}18.1 \\
19.3 \\
19.6\end{array}$ & $\begin{array}{l}\text { Nontern } \\
139.6 \\
139.0 \\
131.4\end{array}$ & $\begin{array}{c}\text { Units, Zv } \\
152.3 \\
152.2 \\
165.8 \\
(163.0)\end{array}$ & $\begin{array}{l}\text { erions } \\
168.1 \\
167.9 \\
169.2 \\
(168.4)\end{array}$ & $\begin{array}{c}170.1,171.5 \\
170.2,171.5 \\
144.6\end{array}$ & & \\
\hline $\begin{array}{l}\text { (Gly-)Leu(-Gly) } \\
\text { (Gly-)Leu(-Tyr) } \\
\text { (Met-)Phe(-Gly) }\end{array}$ & $\begin{array}{l}9.5 \\
9.5\end{array}$ & $\begin{array}{c}18.2 \\
17.8 \\
(18.9) \\
19.1\end{array}$ & $\begin{array}{l}\text { Nonte } \\
140.0 \\
139.9\end{array}$ & $\begin{array}{l}\text { al Units, } \\
152.3 \\
152.5\end{array}$ & $\begin{array}{l}\text { ons } \\
168.1 \\
168.2\end{array}$ & $\begin{array}{l}169.9,171.6 \\
170.3,171.6\end{array}$ & 63.6 & 65.2 \\
\hline
\end{tabular}

$a$ Uncertain assignments are shown along with the next nearest uncertain chemical shift in parentheses. ${ }^{b}$ The shifts listed are for the amino acid unit outside the parentheses. $C$ C-1, C-2, C-3, and C-4 are the numberings of the aromatic carbons. $d C-3$ is assumed to absorb at higher field than $\mathrm{C}-2$, in agreement with published values for toluene. 'Dication. ' Monocation.

Table III. ${ }^{13} \mathrm{C}$ Chemical Shifts (ppm) of the Free Zwitterionic Amino Acids Upfield from Carbon Disulfide ${ }^{a}$

\begin{tabular}{|c|c|c|c|c|c|c|c|}
\hline Amino acids & $\mathrm{C}_{0}$ & $\mathrm{C}_{\alpha}$ & $\mathrm{C}_{\beta}$ & $\mathrm{C}_{\gamma}, \mathrm{C}-1^{b}$ & $C_{8}, C-2^{h}$ & $\mathrm{C}_{e}, \mathrm{C}-3^{b}$ & $C-4^{b}$ \\
\hline $\begin{array}{l}\text { Gly } \\
\text { Leu }\end{array}$ & $\begin{array}{l}19.9 \\
16.8\end{array}$ & $\begin{array}{l}150.9 \\
138.7\end{array}$ & 152.4 & 168.0 & $\begin{array}{l}170.2 \\
171.3\end{array}$ & & \\
\hline $\begin{array}{l}\text { Phe } \\
\text { Ala } \\
\text { Met } \\
\text { Val }\end{array}$ & $\begin{array}{l}18.3 \\
16.6 \\
18.1 \\
18.1\end{array}$ & $\begin{array}{l}136.1 \\
142.1 \\
138.3 \\
131.8\end{array}$ & $\begin{array}{l}155.9 \\
176.1 \\
162.4 \\
163.1\end{array}$ & $\begin{array}{r}56.7^{\circ} \\
163.3 \\
174.2 \\
175.8\end{array}$ & $\begin{array}{r}62.6 \\
178.2\end{array}$ & 62.6 & 64.3 \\
\hline $\begin{array}{l}\text { Lys }{ }^{d} \\
\text { Pro } \\
\text { Arg }\end{array}$ & $\begin{array}{l}18.0 \\
18.8 \\
18.2\end{array}$ & $\begin{array}{l}138.1 \\
131.8 \\
138.3\end{array}$ & $\begin{array}{l}162.7 \\
163.7 \\
164.9\end{array}$ & $\begin{array}{l}171.0 \\
169.0 \\
168.5\end{array}$ & $\begin{array}{l}166.2 \\
146.9 \\
151.9\end{array}$ & 153.4 & \\
\hline
\end{tabular}

${ }^{a}$ From ref $4,{ }^{b} \mathrm{C}-1, \mathrm{C}-2, \mathrm{C}-3$, and $\mathrm{C}-4$ refer to the aromatic carbons of phenylalanine. 'This work; no value listed in ref 4 . Allerhand and coworkers? report $57.3 \mathrm{ppm}$ for $C-1$. ${ }^{\circ}$ The assignments of $C_{\beta}$ and $C_{3}$ are reversed from ref 4 (see text).

bonyl carbons which show upfield shifts of about 2 ppm, the chemical shifts of the other carbons are close to those in the free amino acids.

B. pH-Induced Chemical Shift Changes. On addition of acid, the carboxylate group of a zwitterionic peptide is protonated. The $\mathrm{p} K_{\mathrm{COOH}}$ value of 3.06 for diglycine suggests that at $\mathrm{pH} 1.5$ by far most of the peptide molecules will be in the cationic form. The changes occurring on protonation have been examined by means of proton nmr spectra ${ }^{12,13,19}$ which show that only the resonances of the C-terminal amino acid, where protonation occurs, are shifted significantly downfield. A different effect of carboxylate protonation on cmr shifts has been observed for the protonation of aliphatic carboxylic acid anions ${ }^{20}$ wherein the ${ }^{13} \mathrm{C}$ resonances experience upfield shifts, especially at the carboxylic and $\alpha$ carbons. This pattern is also observed on protonation of the zwitterionic forms of peptides, with significant changes occurring only at the C-terminal units. The effect is attenuated monotonically as a function of the distance of the protonation site. Compared to the zwitterionic peptides, the resonances are upfield by about $3 \mathrm{ppm}$ for the carboxylate carbon, about $2.5 \mathrm{ppm}$ for the $\alpha$ carbon, about $1.2 \mathrm{ppm}$ for the $\beta$ carbon, and about $0.3 \mathrm{ppm}$ for the $\gamma$ carbon. The chemical shifts of protonated tetra- and pentaglycine are very similar to those obtained for the triglycine cation. Only the number of resonances arising from the nonterminal units is different, but not the positions. Because of poor solubility, these two peptides were

(19) M. Sheinblatt, J. Amer. Chem. Soc.., 87, 572 (1965); 88, 2123 $2845(1966)$.

(20) R. Hagen and J. D. Robcrts, ibid., 91, 4504 (1969) examined at $\mathrm{pH} 1.1$ and 0.4 , respectively. The fact that the chemical shifts of the C-terminal glycines agreed well with those of other aminoacylglycines shows that the shifts at $\mathrm{pH} 1.5$ represent those of the cationic peptides. The change of the chemical shifts on protonation of the C-terminal amino acid was only about 60 to $70 \%$ of those for protonation of aliphatic carboxylic acid anions, ${ }^{20}$ and at present, we have no explanation for this difference.

Examination of Tables I and II reveals that on protonation of the C-terminal amino acid of zwitterionic peptides, the carbonyl carbon of the amino acid directly bound to the C-terminal unit shows a downfield shift of up to $0.9 \mathrm{ppm}$. Because this shift is of opposite sign to the shift changes occurring in the C-terminal unit, this downfield shift does not seem to be caused by the charge changes associated with protonation. Three other, more plausible explanations follow: (i) in acidic solution, a small amount of the amide groups is reversibly protonated on oxygen, producing a downfield shift of carbonyl resonance; ${ }^{21}$ (ii) the protonated carboxylate group forms an intramolecular hydrogen

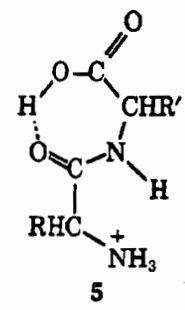

(21) G. Maciel and J. Natterstad, J. Chem. Phy's., 42, 2752 (1965). 
Table IV. ${ }^{18} \mathrm{C}$ Chemical Shift Changes (ppm) of Amino Acids on Incorporation in Peptides and Titration Shifts of Peptides

\begin{tabular}{|c|c|c|c|c|}
\hline Type & $\mathrm{C}_{0}$ & $\mathrm{C}_{\alpha}$ & $\mathrm{C}_{\beta}$ & $\mathrm{C}_{\gamma}$ \\
\hline $\begin{array}{l}\text { Peptide shift of an } \\
\text { N-terminal amino acida }\end{array}$ & $5.4 \pm 1.0$ & $\begin{array}{ll} & 1.3 \pm 0.4 \\
\text { Gly } \quad 0.7 \pm 0.2\end{array}$ & $-0.2 \pm 0.5$ & $0.4 \pm 0.5$ \\
\hline $\begin{array}{l}\text { Peptide shift of a } \\
\text { C-terminal amino acid }\end{array}$ & $-3.5 \pm 1.0$ & Gly $-2.0 \pm 0.5$ & $-1.2 \pm 0.6$ & $-0.4 \pm 0.3$ \\
\hline $\begin{array}{l}\text { Peptide shift of a } \\
\text { nonterminal amino acidc }\end{array}$ & $1.5 \pm 1.0$ & $\begin{array}{r}0.6 \pm 0.4 \\
\text { Gly }-1.1 \pm 0.1\end{array}$ & $0.0 \pm 0.5$ & $0.0 \pm 0.1$ \\
\hline $\begin{array}{l}\text { Titration shift of } \\
\text { N-terminal unit }{ }^{d, s}\end{array}$ & $-6.9 \pm 1.0$ & $\begin{array}{r}-1.0 \pm 0.5 \\
\text { Gly }-2.6 \pm 0.2\end{array}$ & $-3.1 \pm 1.0$ & $-0.6 \pm 0.4$ \\
\hline $\begin{array}{l}\text { Titration shift of } \\
\text { C-terminal unit }\end{array}$ & $3.0 \pm 0.5$ & $\begin{array}{ll} & 2.6 \pm 0.5 \\
\text { Gly } \quad 2.2 \pm 0.1\end{array}$ & $1.2 \pm 0.2$ & $0.3 \pm 0.2$ \\
\hline
\end{tabular}

a Difference between the chemical shifts of an N-terminal amino acid in a zwitterionic peptide and the corresponding free, zwitterionic amino acid. 'Difference between the chemical shifts of a C-terminal amino acid in a zwitterionic peptide and the corresponding free, zwitterionic amino acid. 'Difference between the chemical shifts of a nonterminal amino acid in a zwitterionic peptide and the corresponding free amino acid. dDifference between the chemical shifts of an N-terminal amino acid in peptide as anion and zwitterion. $\bullet$ The values for pH 9.5 of the anion solution are probably too small by up to $30 \%$ for higher pH values. 'Difference between the chemical shifts of a C-terminal amino acid in a peptide as cation and zwitterion.

bond to the carbonyl oxygen (5), also leading to a downfield shift on the carbonyl carbon; ${ }^{21}$ and (iii) the two charged groups in the zwitterions attract one another sufficiently to stabilize the cis configuration of the peptide bond (6). ${ }^{22}$ It would then be expected that, with

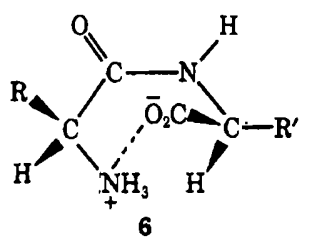

respect to the $\mathrm{C}-\mathrm{N}$ bond in the $\mathrm{C}$-terminal amino acid, the carboxylate and the carbonyl group be drawn into at least a cis-gauche conformation (7) to each

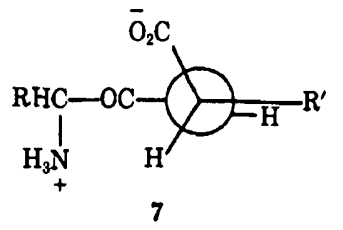

other, if not one in which they are completely eclipsed. The resulting steric $\gamma$ interaction should produce an upfield change of the carbonyl resonance. After the protonation of the carboxylate group, there would be no reason to maintain the strained conformation 7 , and the trans configuration at the peptide bond would be the predominant one which, as a consequence, should have the carbonyl resonance at lower field.

Possibility iii suggests that the same downfield shift should appear on going from neutral to alkaline media as from neutral to acidic media, because in alkaline solution the ammonium group is neutralized and the strong electrostatic attraction eliminated. Measurements on the dipeptides supply no information in this regard because with these substances, the deprotonation has a different and large effect on the carbonyl group resonance (vide infra) which would mask the rather small shifts expected for the conformational change. In four of five tripeptides, however, a downfield shift does occur of up to $0.8 \mathrm{ppm}$ for the carbonyl resonance of the middle unit in the anion as compared to the

(22) I. Z. Siemion and A. Sucharda-Sobczyk, Tetrahedron, 26, 191 (1970). zwitterion. With glycylleucylglycine, this effect is absent. No decision seems possible among these alternatives at this time.

On going from neutral to alkaline media, the peptide zwitterions are deprotonated at the ammonium group and turn to anions. At $\mathrm{pH} 9.5$, for example, where most of all diglycine molecules $\left(\mathrm{p} K_{\mathrm{NH}_{3}}=8.13^{11}\right)$ should have lost one proton, the proton nmr shows upfield shifts limited to the deprotonated amino acid unit. ${ }^{12,13,19}$ In the carbon-13 spectra, downfield shifts take place only in the $\mathrm{N}$-terminal amino acid and in the carbonyl resonances of the middle units in tripeptides (vide supra). The resonance of the $\alpha$ carbon directly bound to the deprotonated nitrogen is not greatly affected, up to $-2.5 \pm 0.1 \mathrm{ppm}$ for glycine units, and rather less for the other amino acids $(-1.0 \pm 0.5$ ppm). Contrary to what might be expected from the shifts associated with deprotonation of the carboxyl group, there is no monotonic diminution of shift changes as a function of the distance from the reaction center. Indeed, the downfield changes at the $\beta$ carbons of $3.1 \pm 0.8 \mathrm{ppm}$ and of the carbonyl carbon of $6.9 \pm 1$ ppm are substantially larger than the change at the $\alpha$ carbons. Sternlicht and coworkers ${ }^{4,14}$ have discussed the origin of the downfield shift of the $\alpha$ carbon in some detail. The much larger downfield change of the carbonyl compared to the $\beta$-carbon resonances seems associated with the $\mathrm{sp}^{2}$ hybridization of the carbonyl carbon. This conclusion is supported by the fact that the $\mathrm{sp}^{2}$ hybridized carbons, including carbons such as the C-1 aromatic carbons of phenylalanine, seem to show the largest shift effects on protonation or deprotonation (see Table IV).

Another experimental finding deserves attention. Tetra- and pentaglycine were examined in solutions of $\mathrm{pH} 10.2$ and 11.2, respectively, because of poor solubility at $\mathrm{pH}$ 9.5. The C-terminal and middle units generally have the expected chemical shifts, even if the carbonyl carbons of the middle units show a variation of $1.3 \mathrm{ppm}$. The shifts of the N-terminal amino acids, however, deviate considerably from those of the dipeptides. The carbonyl carbon and the $\alpha$ carbon are more downfield by about 3 and $0.6 \mathrm{ppm}$, respectively. At the higher $\mathrm{pH}$ values, the deprotonation of the ammonium group is presumably complete, a situation which is apparently not always achieved at $\mathrm{pH} 9.5$. 
4572

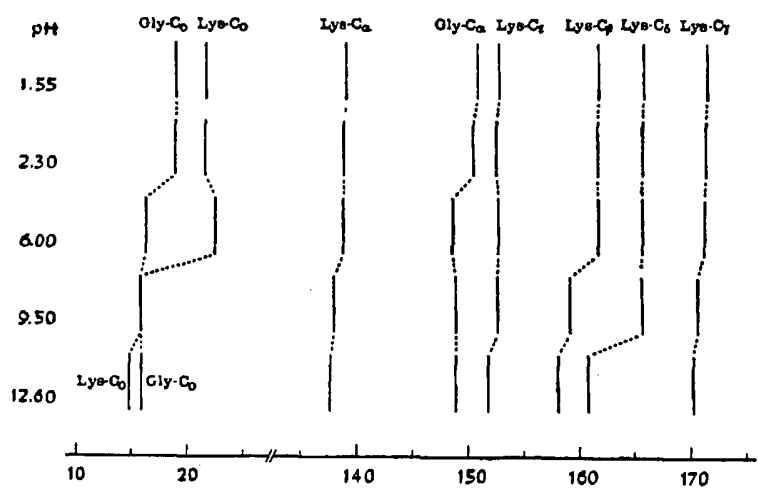

Figure 1. pH-dependent ${ }^{13} \mathrm{C}$ chemical shifts in L-lysylglycine in ppm upfield from carbon disulfide.

Other evidence for incomplete deprotonation at $\mathrm{pH}$ 9.5 is seen from the greater downfield shifts of the $\mathrm{N}$ terminal carbonyl carbons of triglycine and glycylleucylglycine which have a $\mathrm{p} K_{\mathrm{NH}_{3}}$ - of $7.91,{ }^{11}$ compared to glycylleucine with a $\mathrm{p} K_{\mathrm{NH}_{3}-}$ of 8.29. ${ }^{11}$ It may be that many of the N-terminal titration shifts will increase up to $30 \%$ at higher pH's, as was found to be the case with lysylglycine (vide infra).

The various shift trends are summarized in Table IV, along with the observed extreme deviations. It will be seen that the glycine $\alpha$ carbons behave differently than the $\alpha$ carbons of the other amino acids, as might be expected on the basis of the different degree of substitution. Because of the special abnormalities mentioned earlier, the effects derived from peptides containing proline are not included in Table IV.

C. Special Effects Associated with Particular Amino Acids. The special effect of proline on its N-terminal neighbors has already been discussed. In free leucine, the methyl groups are magnetically nonequivalent. In the zwitterion, the difference of the chemical shifts is $1.1 \mathrm{ppm}$. The origin of this effect is considered to arise from incomplete averaging of electric field gradients in those situations where there is free rotation and no preferred conformations or, and more importantly, because of preferred conformations in which, on the average, the methyl groups are in nonequivalent magnetic environments. ${ }^{23,24}$ The latter possibility has been used to explain the nonequivalence of glycine methylene protons in aminoacylglycines. ${ }^{13}$ The nonequivalence of isopropyl methyl carbons in carbon-13 $\mathrm{nmr}$ has been investigated for some alcohols and hydrocarbons ${ }^{24}$ and the chemical shift difference was found to depend strongly on the steric requirement of the substituents on the carbon to which the isopropyl group is attached, as would indicate differences in conformational populations. In a hydrocarbon with one methylene group between the isopropyl group and the chiral carbon, the methyl shift difference was $1.0 \mathrm{ppm}{ }^{24}$ This is close to the difference in leucine itself, but not to what is found if the leucine is part of a peptide. N-Terminal leucines show a difference of $0.5 \mathrm{ppm}$, while with C-terminal leucine, the difference is $1.5 \mathrm{ppm}$. The Newman projections

(23) J. A. Pople, Mol. Phjs., 1, I (1958).

(24) J. I. Kroschwitz, M. Winokur, H. J. Reich, and J. D. Roberts, J. Amer. Chem. Soc., 91, 5927 (1969), and references cited therein.

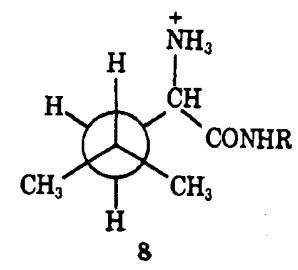

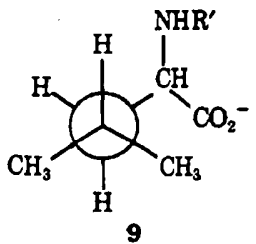

8 and 9 suggest the difference in the charge distribution is the important factor, and this is supported by the fact that the chemical shift difference in 8 rises to $0.8 \mathrm{ppm}$ when the ammonium group is deprotonated. The isopropyl group of a nonterminal leucine unit shows similar effects to those of a C-terminal leucine unit.

As mentioned earlier, the effects of changes in charge are also noticeable in the phenyl groups of phenylalanine. Thus, the resonance of $\mathrm{C}-1$ in an N-terminal unit in alkaline solution appears about $3 \mathrm{ppm}$ at lower field than in neutral or acidic solution. For C-terminal phenylalanine units, the shift runs up only to about 1 ppm because of the greater distance to the reaction center. Again, these shifts (which are $\gamma$ shifts) are much larger than the $\gamma$ shifts of $\mathrm{sp}^{3}$ hybridized carbons summarized in Table IV.

Lysylglycine is a peptide with a basic amino acid unit. The chemical shifts of this peptide at five $\mathrm{pH}$ values are outlined in Figure 1. At pH 1.55, the substance exists as a dication. Not much change occurs

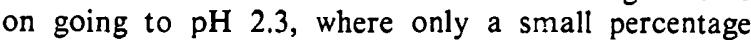

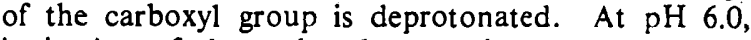
ionization of the carboxyl group is nearly complete, as can be seen from the downfield shifts of the glycine resonances and the upfield shift of the lysine carbonyl peak. Proceeding to $\mathrm{pH} 9.5$, most $\alpha$-ammonium groups of the lysine moiety become deprotonated and the zwitterion is now the predominating species. Finally, at $\mathrm{pH} 12.6$, the $\epsilon$-ammonium group also loses a proton. The titration shifts for $\mathrm{N}$-terminal units in Table IV indicate that the $\beta$ and $\delta$ resonances assigned previously for lysine as the amino acid cation ${ }^{4}$ should be reversed. Deprotonation of the $\epsilon$-ammonium group produces a larger effect on the more remote $\delta$ carbon $(-5 \mathrm{ppm})$ than on the $\epsilon$ carbon $(-1.2 \mathrm{ppm})$, in agreement with the results obtained on deprotonation of $\alpha$-ammonium groups. This effect would seem to have considerable importance for structural diagnosis. A possible explanation for this behavior may reside in a competition between two effects brought into play on deprotonation of the ammonium group. ${ }^{25}$ One of these could be an electrostatic effect associated with the change in charge, while the other could be associated with a change in electronegativity of the nitrogen, resulting from deprotonation of the ammonium group, and this would be basically an inductive effect. The latter effect would be an upfield shift, while the first would be a downfield shift. Studies of the substituent effects of hydroxyl and methyl groups indicate that the inductive effects of substituents seem to produce major shift influences only on those carbons to which the substituents are directly attached. ${ }^{26}$ If then the electro-

(25) F. R. N. Gurd, P. J. Lawson, D. W. Cochran, and E. Wenkert, J. Biol. Chem., 246, 3725 (1971), have reached similar conclusions. (26) J. D. Roberts, F. J. Weigert, J. I. Kroschwitz, and H. J. Reich, J. Amer. Chem. Soc., 92, 1338 (1970). 
static effects fall off more slowly with distance from the point of substitution, the more remote carbons will be primarily influenced by them and the net effect at the $\beta$ carbons could well be larger than at the $\alpha$ carbons. In the deprotonation of aliphatic carboxylic acids, the charge effect at the carboxyl carbon, which is $\mathrm{sp}^{2}$ hybridized, is probably rather high. Therefore, in this case, the upfield shift, which is expected from the change of the electronegativity of the oxygen by ionization, is not large enough to make the overall shift smaller than the downfield shift displayed by the a carbon. ${ }^{20}$ Small downfield movements of the lysine carbonyl- and $\beta$-carbon resonances between $\mathrm{pH} 9.5$ and 12.6 again suggest that at $\mathrm{pH} 9.5$ the $\alpha$-ammonium group is not deprotonated completely.

\section{Conclusions}

Carbon-13 nmr provides a convenient, nondestructive method for the determination of the amino acid sequence in di- and tripeptides. Essentially all of the necessary information can be obtained from the spectrum of the zwitterions, but the $\mathrm{pH}$-induced shifts may also be helpful to facilitate or confirm assignments. The data here reported appear to have considerable value for interpretation of the spectra of complex polypeptides and proteins where the proton resonance lines may overlap too much to be very useful. However, it remains to be seen to what degree the secondary and tertiary structures of these compounds will influence the carbon-13 chemical shifts of the individual amino acids.

\title{
Magnetic Resonance Studies of Protein-Small Molecule Interactions. Binding of $N$-Trifluoroacetyl-D-(and L-)-p-fluorophenylalanine to $\alpha$-Chymotrypsin
}

\author{
Kenneth L. Gammon, Stephen H. Smallcombe, and John H. Richards* \\ Contribution No. 4319 from the Gates and Crellin Laboratories of Chemistry, \\ California Institute of Technology, Pasadena, California 91109. \\ Received October 6, 1971
}

\begin{abstract}
Magnetic resonance studies of the interaction of $N$-trifluoroacetyl-D-(and L-) $p$-fiuorophenylalanine with $\alpha$-chymotrypsin have been used to investigate the molecular details of the enzyme-inhibitor interaction including the effect of $\mathrm{pH}$ (from 5.0 to 8.0). The principles of the technique are described. We conclude that the trifluoroacetyl group of the D isomer interacts with the catalytic locus (His-57, Ser-195) while that of the $\mathrm{L}$ isomer is directed toward Ser-214. The aromatic ring of both the $\mathrm{D}$ and $\mathrm{L}$ isomer resides in the hydrophobic pocket. The binding constant for the $\mathrm{D}$ isomer increases with neutralization of a group which has $\mathrm{p} K_{\mathrm{B}}$ of 6.6 in the free-enzyme (presumably His-57). The dimerization of chymotrypsin strongly affects the quantitative results and has been explicitly included in the analysis.
\end{abstract}

$\mathrm{I}^{\mathrm{n}}$

recent years magnetic resonance techniques have been widely and productively used to gain insight into the molecular details of interactions between proteins and small molecules (usually enzymes and their specific substrates or inhibitors) ${ }^{1-4}$ Studies of the binding of inhibitors to $\alpha$-chymotrypsin have been a particularly popular endeavor and information has been reported regarding the way in which the chemical shifts $^{2,5-10}$ or relaxation characteristics ${ }^{7,11,12}$ of various nuclei of different inhibitors change when the inhibitor

(1) E. W. Thomas, Biochem. Biophys. Res. Commun., 24, 611 (1966).

(2) T. M. Spotswood, J. M. Evans, and J. H. Richards, J. Amer. Chem. Soc., 89, 5052 (1967).

(3) F. W. Dahlquist and M. A. Raftery, Biochemistry, 7, 3269 (1968).

(4) J. C. K. Roberts and O. Jardetsky, Adtan. Protein Chem., 24, 447 (1970).

(5) E. Zeffren and R. E. Reavill, Biochem. Biophys. Res. Commun., 32, 73 (1968).

(6) B. D. Sykes, ibid., 33, 727 (1968).

(7) B. D. Sykes, J.Amer. Chem. Soc., 91,949 (1969).

(8) J. T. Gerig and J. D. Reinheimer, ibid., 92, 3146 (1970)

(9) J. T. Gerig and R. A. Rimerman, Biochem. Biophy's. Res. Commun., 40, 1149 (1970).

(10) H. Ashton and B. Capon, J. Chem. Soc. D, 513 (1971).

(11) J. T. Gerig, J. Amer. Chem. Soc., 90, 2681 (1968).

(12) E. W. Bittner and J. T. Gerig, ibid., 92, 5001 (1970) binds at the active site of $\alpha$-chymotrypsin. The purpose of the present paper is to report the details of the technique and its application to a study of the binding of $N$-trifluoroacetyl-D-(and L-)- $p$-fluorophenylalanine. As a function of $\mathrm{pH}$, we monitored the changes in chemical shifts of the two kinds of fluorine nuclei on interaction with the active site of $\alpha$-chymotrypsin, as well as the enzyme-inhibitor dissociation constants. Dimerization of $\alpha$-chymotrypsin ${ }^{13-18}$ strongly perturbs the quantitative conclusions from these studies and was explicitly included in our analysis.

Principles of the Method. Exchange Rates. The method on which the work of this paper is based depends upon exchange between solution and the protein of the small molecule containing the nuclei whose magnetic resonance characteristics are being observed.

(13) M. S. N. Rao and G. Kegeles, ibid, 80, 5724 (1958).

(14) F. J. Kezdy and M. L. Bender, Biochemistry, 4, 104 (1965),

(15) L. D. Faller and R. E. LaFond, ibid., 10,1033 (1971).

(15) L. D. Faller and R. E. LaFond, ibid,, 10, 1033 (1971).

(16) K. C. Aune and S. N. Timasheff, ibid., 10, 1609 (1971),
(17) S. N. Timasheff, Arch. Biochem. Biophys., 132, 165 (1969)

(18) K. C. Aune, L. C. Goldsmith, and S. N. Timasheff, Biochemistry, 10, 1617 (1971). 